Check for updates

Cite this: Chem. Commun., 2020, 56, 9823

Received 3rd July 2020

Accepted 15th July 2020

DOI: 10.1039/d0cc04606

rsc.li/chemcomm

\section{Selective strain-promoted azide-alkyne cycloadditions through transient protection of bicyclo[6.1.0]nonynes with silver or gold $\dagger$}

\author{
Keisuke Adachi, ${ }^{a}$ Tomohiro Meguro, ${ }^{a}$ Yuki Sakata, ${ }^{a}$ Kazunobu Igawa, (D) ${ }^{b}$ \\ Katsuhiko Tomooka, (D) ${ }^{b}$ Takamitsu Hosoya (D) ${ }^{a}$ and Suguru Yoshida (D) *a
}

Complexation of bicyclo[6.1.0]nonynes with a cationic silver or gold salt results in protection from a click reaction with azides. The cycloalkyne protection using the silver or gold salt enables selective strain-promoted azide-alkyne cycloadditions of diynes keeping the bicyclo[6.1.0]nonyne moiety unreacted.

Click reactions, such as strain-promoted azide-alkyne cycloaddition (SPAAC) using cycloalkynes, have been used for reliable molecular conjugation in a broad range of research fields including materials chemistry, pharmaceutical sciences, and chemical biology. ${ }^{1-7}$ In particular, remarkable reactivities of bicyclo[6.1.0]nonynes (BCNs) realized catalyst-free functionalizations by reaction with a number of ynophiles such as azides, nitrones, nitrile oxides, tetrazines, triazines, sydnones, thiophene $S, S$-dioxides, and so on. ${ }^{5}$ In the course of our studies on click chemistry, ${ }^{6}$ we recently developed a transient protection method for cycloalkynes involving BCNs from the SPAAC reaction by complexation with $(\mathrm{MeCN})_{4} \mathrm{CuBF}_{4}$, which was easily deprotected by treatment with chelators (Fig. 1A). ${ }^{7}$ A wide variety of functionalized cycloalkynes were synthesized using an azide-to-cycloalkyne switching approach by the protection of a cycloalkyne having a terminal alkyne moiety with $(\mathrm{MeCN})_{4} \mathrm{CuBF}_{4}$ followed by copper-catalyzed azide-alkyne cycloaddition (CuAAC) with functionalized azides and subsequent deprotection with an aqueous solution of disodium ethylenediaminetetraacetate (EDTA-2Na) (Fig. 1B). ${ }^{8}$ We herein disclose a selective protection method for BCNs from other cycloalkynes by silver or gold complexation, realizing facile synthesis of functionalized BCNs by selective SPAAC reactions using diyne platforms leaving the BCN moiety intact (Fig. 1C).

\footnotetext{
${ }^{a}$ Laboratory of Chemical Bioscience, Institute of Biomaterials and Bioengineering, Tokyo Medical and Dental University (TMDU), 2-3-10 Kanda-Surugadai, Chiyoda-ku, Tokyo 101-0062, Japan. E-mail: s-yoshida.cb@tmd.ac.jp ${ }^{b}$ Institute for Materials Chemistry and Engineering, Kyushu University, 6-1 Kasuga-koen, Kasuga, Fukuoka 816-8580, Japan

$\dagger$ Electronic supplementary information (ESI) available: Experimental procedures and characterization for the new compounds including NMR spectra. See DOI: 10.1039/d0cc04606j
}

A

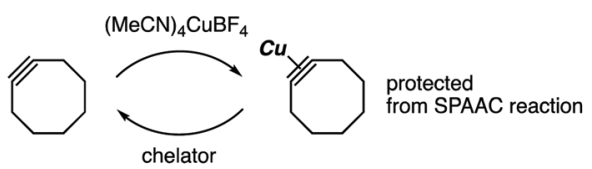

B



C This work

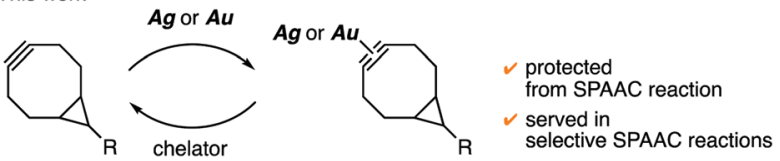

Fig. 1 Protection methods of cycloalkynes. (A) Protection with copper. (B) The azide-to-cycloalkyne switching approach. (C) This work. FG = functional group.

With previous reports of cyclooctyne-metal complexes in mind, ${ }^{9,10}$ we envisioned that silver and gold salts can protect cycloalkynes from the SPAAC reaction by complexation. Thus, we screened silver and gold salts in the complexation with BCN 1a in $\mathrm{CDCl}_{3}$ followed by the addition of azide $2 \mathbf{a}$ (Table 1 ). As a result, a variety of silver salts decreased the yield of triazole $3 \mathbf{a}$ along with the recovery of azide $\mathbf{2 a}$ and precipitate formation of 1a-metal complexes (entries 2-7), while azide $2 \mathbf{a}$ was completely consumed when the reaction was performed without any metal salt (entry 1). In particular, the examination using $\mathrm{AgBF}_{4}$ resulted in no triazole formation and almost complete recovery of azide 2a (entry 7), clearly showing that the cationic silver salt completely prevented the SPAAC reaction. Furthermore, $\mathrm{AuBF}_{4}$ prepared from $\mathrm{AuCl}$ and $\mathrm{AgBF}_{4}$ also realized the protection of cycloalkyne 1a from the SPAAC reaction (entry 8).

Deprotection of BCN-metal complexes $1 \mathbf{a}-\mathrm{AgBF}_{4}$ and $\mathbf{1 a}-\mathrm{AuBF}_{4}$ was achieved by proper choice of the silver and gold salts, and

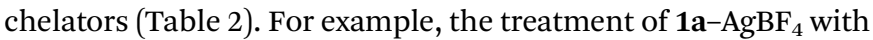


Table 1 Screening of metal salts for the protection of cycloalkyne 1a from the formation of $3 a$

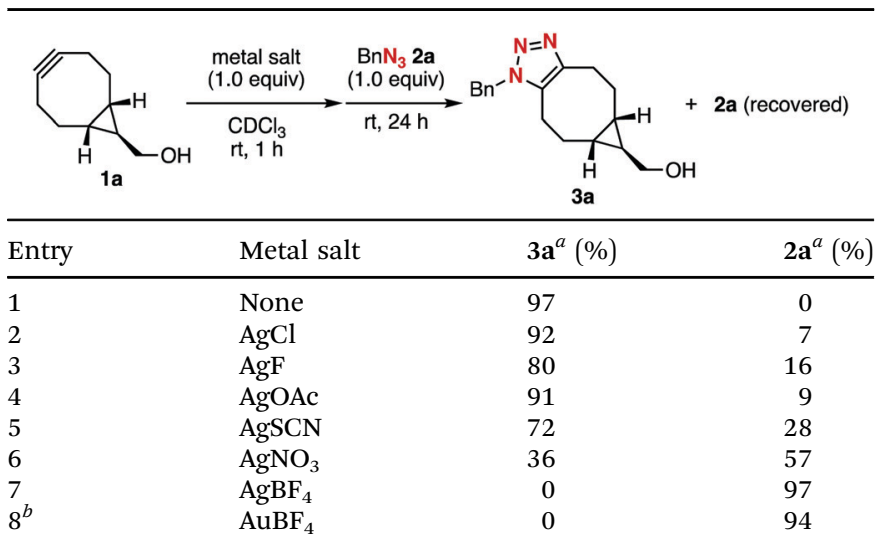

${ }^{a}$ Yields were determined using ${ }^{1} \mathrm{H}$ NMR analysis. ${ }^{b} \mathrm{AuBF}_{4}$ was prepared from $\mathrm{AuCl}$ and $\mathrm{AgBF}_{4}$.

Table 2 Screening of chelators for the deprotection of $\mathrm{BCN}$-metal salts

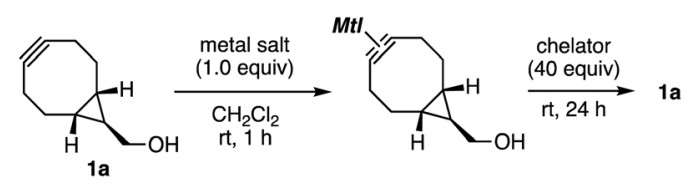

\begin{tabular}{|c|c|c|c|}
\hline Entry & Metal salt & Chelator & $1 \mathrm{a}^{a}(\%)$ \\
\hline 1 & $\mathrm{AgBF}_{4}$ & $15 \mathrm{M}$ aq. $\mathrm{NH}_{3}$ & 55 \\
\hline 2 & $\mathrm{AgBF}_{4}$ & $0.1 \mathrm{M}$ aq. EDTA.2Na & 15 \\
\hline 3 & $\mathrm{AgBF}_{4}$ & SiliaMetS Thiourea & 69 \\
\hline $4^{b}$ & $\mathrm{AgBF}_{4}$ & SiliaMetS Thiourea & 93 \\
\hline $5^{b}$ & $\mathrm{AgBF}_{4}$ & Resin(polystyrene)-PPh ${ }_{2}$ (PS-TPP) & 82 \\
\hline $6^{c}$ & $\mathrm{AuBF}_{4}$ & $15 \mathrm{M}$ aq. $\mathrm{NH}_{3}$ & 0 \\
\hline $7^{c}$ & $\mathrm{AuBF}_{4}$ & $0.1 \mathrm{M}$ aq. EDTA-2Na & 24 \\
\hline $8^{b, c}$ & $\mathrm{AuBF}_{4}$ & SiliaMetS Thiourea & 58 \\
\hline $9^{b, c, d}$ & $\mathrm{AuBF}_{4}$ & SiliaMetS Thiourea & 83 \\
\hline $10^{b, c}$ & $\mathrm{AuBF}_{4}$ & Resin(polystyrene)-PPh ${ }_{2}$ (PS-TPP) & 0 \\
\hline
\end{tabular}

${ }^{a}$ Yields were determined using ${ }^{1} \mathrm{H}$ NMR analysis. ${ }^{b}$ Chelators (80 equiv.) were used. ${ }^{c} \mathrm{AuBF}_{4}$ was prepared from $\mathrm{AuCl}$ and $\mathrm{AgBF}_{4} \cdot{ }^{d}$ THF was used instead of $\mathrm{CH}_{2} \mathrm{Cl}_{2}$.

an aqueous solution of ammonia or EDTA. $2 \mathrm{Na}$ resulted in the recovery of 1a in low to moderate yields along with the decomposition of cycloalkyne 1a (entries 1 and 2). In sharp contrast, the deprotection of $1 \mathbf{a}-\mathrm{AgBF}_{4}$ with a solid-phase metal scavenger SiliaMetS Thiourea proceeded efficiently (entry 3 ). In particular, increasing the amount of SiliaMetS Thiourea improved the recovery yield (entry 4 ). The deprotection of $\mathbf{1 a}-\mathrm{AgBF}_{4}$ with a polystyrene-conjugated phosphine also took place smoothly (entry 5). Among a variety of conditions screened for the deprotection of $\mathbf{1 a}-\mathrm{AuBF}_{4}$ (entries 6-10), we succeeded in the efficient deprotection with SiliaMetS Thiourea in THF (entry 9).

Attempts to protect dibenzo-fused cyclooctyne (DIBO) $\mathbf{1 b}^{\mathbf{1 1}}$ and 4,8-diazacyclononyne (DACN) $1 \mathrm{c}^{12}$ with silver or gold revealed their decreasing coordination strength compared to the complex between BCN 1a and silver or gold (Table 3). When $(\mathrm{MeCN})_{4} \mathrm{CuBF}_{4}$ was used, cycloalkynes $\mathbf{1 b}$ and $\mathbf{1 c}$ were successfully protected resulting in the recovery of azide $2 \mathbf{a}$ in excellent yields (entries 1 and 4). On the other hand, the treatment of
Table 3 Screening of metal salts for the protection of cycloalkynes $\mathbf{1 b}$ and $1 \mathrm{c}$

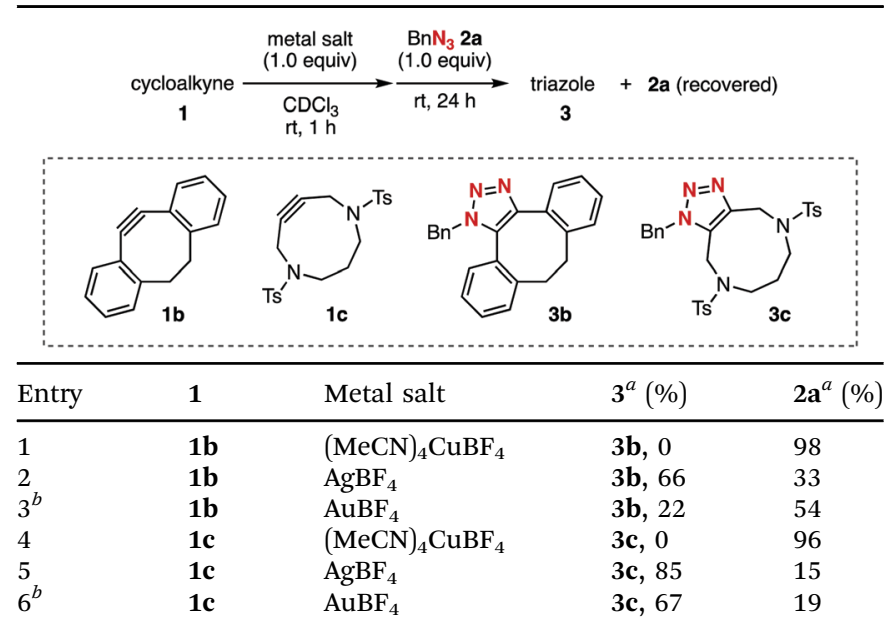

${ }^{a}$ Yields were determined using ${ }^{1} \mathrm{H}$ NMR analysis. ${ }^{b} \mathrm{AuBF}_{4}$ was prepared from $\mathrm{AuCl}$ and $\mathrm{AgBF}_{4}$.

cycloalkynes $\mathbf{1 b}$ and $\mathbf{1 c}$ with $\mathrm{AgBF}_{4}$ or $\mathrm{AuBF}_{4}$ in $\mathrm{CDCl}_{3}$ followed by the addition of azide $2 \mathbf{a}$ furnished triazoles $\mathbf{3 b}$ and $\mathbf{3 c}$ in low to high yields (entries 2, 3, 5, and 6). Of note, the coordination strength between DACN 1c and silver or gold was significantly weak, leading to the recovery of azide $2 \mathrm{a}$ in low yields. These results clearly show the contrasting differences in the complexation of cycloalkynes with copper, silver, and gold depending on the electronic nature and ring strain of cycloalkynes.

Complexation of $\mathrm{BCN}$ 1a with $\mathrm{AgBF}_{4}$ served as protection from [2+3] cycloaddition with nitrone 4 (Table 4 ). While BCN $1 a$ smoothly reacted with nitrone $\mathbf{4}$ without the protection providing dihydroisoxazole 5 in high yield (entry 1), complexation of BCN 1a with transition metals prevented the cycloalkyne-nitrone cycloaddition (entries 2-4). ${ }^{13}$ However, nitrone 4 was consumed completely by decomposition when using $(\mathrm{MeCN})_{4} \mathrm{CuBF}_{4}$ or $\mathrm{AuBF}_{4}$ (entries 2 and 4). On the other hand, the complexation of $1 \mathrm{a}$ with $\mathrm{AgBF}_{4}$ realized the protection of $\mathrm{BCN} 1 \mathrm{a}$ along with the recovery of nitrone $\mathbf{4}$ in good yield (entry 3 ).

Table 4 Screening of metal salts for the protection of cycloalkyne 1a from formation of $\mathbf{5}$



\begin{tabular}{llcl}
\hline Entry & Metal salt & $\mathbf{5}^{a}(\%)$ & $\mathbf{4}^{a}(\%)$ \\
\hline 1 & None & 93 & 0 \\
2 & $(\mathrm{MeCN})_{4} \mathrm{CuBF}_{4}$ & 0 & Decomposed \\
3 & $\mathrm{AgBF}_{4}$ & 0 & 93 \\
$4^{b}$ & $\mathrm{AuBF}_{4}$ & 0 & Decomposed
\end{tabular}

${ }^{a}$ Yields were determined using ${ }^{1} \mathrm{H}$ NMR analysis. ${ }^{b} \mathrm{AuBF}_{4}$ was prepared from $\mathrm{AuCl}$ and $\mathrm{AgBF}_{4}$. 
Table 5 Screening of metal salts for the selective protection of cycloalkynes

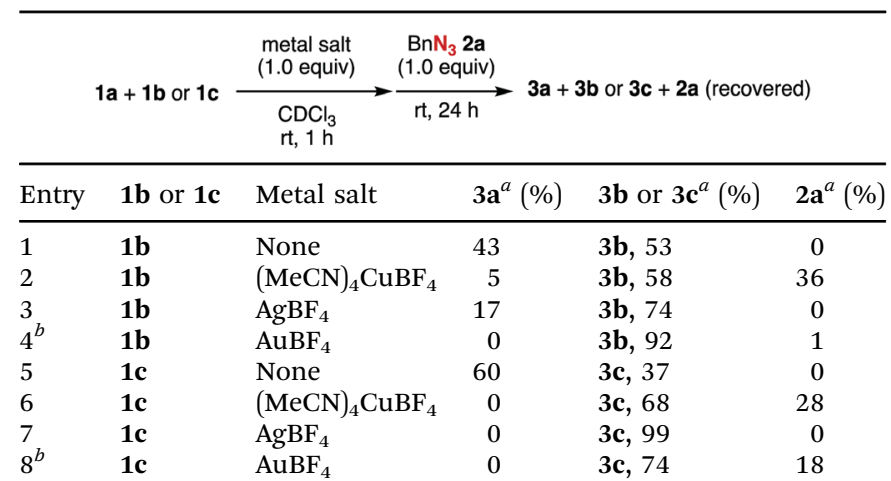

${ }^{a}$ Yields were determined using ${ }^{1} \mathrm{H}$ NMR analysis. ${ }^{b} \mathrm{AuBF}_{4}$ was prepared from $\mathrm{AuCl}$ and $\mathrm{AgBF}_{4}$.

Complexation with silver or gold realized the selective protection of BCN in the presence of other cycloalkynes (Table 5). An equimolar mixture between BCN 1a and DIBO $1 \mathrm{~b}$ (1.0 equiv. each) smoothly reacted with benzyl azide (2a) (1.0 equiv.) without protection to furnish a ca. 1:1.2 mixture of triazoles 3a and $\mathbf{3 b}$ (entry 1). The pretreatment of cycloalkynes $\mathbf{1 a}$ and $\mathbf{1 b}$ (1.0 equiv. each) with 1.0 equiv. of metal salts drastically changed the ratio of $\mathbf{3 a}$ to $\mathbf{3} \mathbf{b}$ (entries 2-4). In particular, we succeeded in the selective SPAAC reaction of DIBO $\mathbf{1 b}$ affording triazole $\mathbf{3 b}$ in high yield when using $\mathrm{AuBF}_{4}$ by virtue of the $\mathrm{BCN}$-selective protection (entry 4). The SPAAC reaction of an equimolar mixture of BCN 1a and DACN 1c with azide 2a also proceeded efficiently to provide a $c a$. 1.6:1 mixture of triazoles $3 \mathrm{a}$ and $3 \mathbf{c}$ (entry 5). The pretreatment of cycloalkynes $\mathbf{1 a}$ and $\mathbf{1 c}$ with metal salts prevented the formation of triazole $3 \mathbf{a}$ (entries 6-8). In particular, treatment of cycloalkynes $1 \mathrm{a}$ and $1 \mathrm{c}$ (1.0 equiv. each) with $\mathrm{AgBF}_{4}$ (1.0 equiv.) followed by the addition of azide 2a exclusively furnished triazole $3 \mathbf{c}$ in excellent yield (entry 7 ).

The synthetic utility of the DIBO- and DACN-selective SPAAC reactions in the presence of a $\mathrm{BCN}$ moiety through the complexation was showcased by the selective triazole formation of diynes 6 and 8 keeping the BCN moiety unreacted (Fig. 2). Indeed, the pretreatment of diyne 6 with $\mathrm{AuBF}_{4}$ followed by the addition of azide $\mathbf{2 b}$ and subsequent removal of the gold salt with SiliaMetS Thiourea provided triazole 7 in good yield by the SPAAC reaction at the DIBO moiety without reacting the BCN moiety (Fig. 2A). Furthermore, we also achieved the DACN-selective triazole formation of diyne 8 by complexation with $\mathrm{AgBF}_{4}$, addition of azide $\mathbf{2} \mathbf{b}$, and the removal of the silver salt with SiliaMetS Thiourea (Fig. 2B). Since the remaining BCN moiety contributes significantly to the catalyst-free click conjugation with various ynophiles in materials chemistry and chemical biology, the DIBO- and DACN-selective triazole formation of diynes allowed for sequential conjugations of a broad range of functional molecules. ${ }^{5}$

In conclusion, we have developed an efficient method for the transient protection of BCNs by complexation with silver or gold, enabling DIBO- or DACN-selective triazole formation. ${ }^{14}$ The selective SPAAC reactions realized the preparation of functionalized BCNs by the selective click conjugation of diynes. Further studies of cycloalkyne-metal complexes involving detailed solvent effects,
A



B

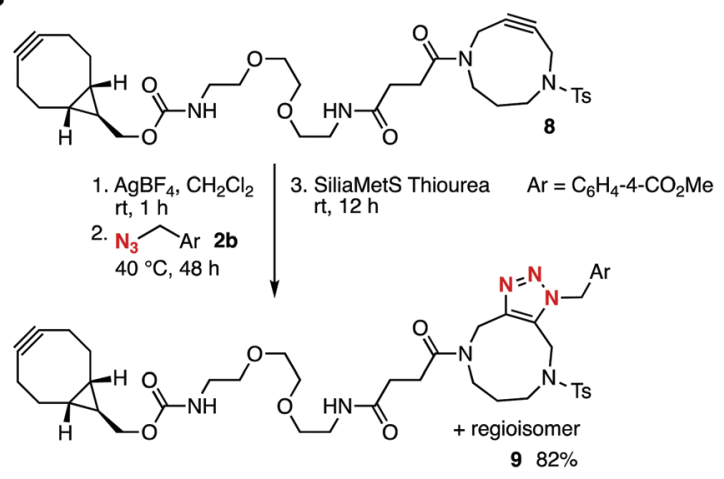

Fig. 2 Selective SPAAC reactions of diynes $\mathbf{6}$ and $\mathbf{8}$. (A) Selective reaction of $\mathbf{6}$. (B) Selective reaction of $\mathbf{8}$.

protection from various ynophiles, and applications of sequential triazole formations of diynes are now in progress.

This work was supported by JSPS KAKENHI Grant Numbers JP19K05451 (C; S. Y.), JP18J11113 (JSPS Research Fellow; T. M.), JP18H02104 (B; T. H.), and JP18H04386 (Middle Molecular Strategy; T. H.); the Naito Foundation (S. Y.); the Japan Agency for Medical Research and Development (AMED) under Grant Number JP20am0101098 (Platform Project for Supporting Drug Discovery and Life Science Research, BINDS); the Cooperative Research Project of Research Center for Biomedical Engineering; and the Research Program of "Five-Star Alliance" in "NJRC Mater. \& Dev."

\section{Conflicts of interest}

There are no conflicts to declare.

\section{Notes and references}

1 (a) H. C. Kolb, M. G. Finn and K. B. Sharpless, Angew. Chem., Int. Ed., 2001, 40, 2004; (b) C. S. McKay and M. G. Finn, Chem. Biol., 2014, 21, 1075; (c) J. Lahann, Click Chemistry for Biotechnology and Materials Science, John Wiley \& Sons, West Sussex, 2009.

2 M. Meldal and C. W. Tornøe, Chem. Rev., 2008, 108, 2952.

3 (a) M. F. Debets, C. W. J. van der Doelen, F. P. J. T. Rutjes and F. L. van Delft, ChemBioChem, 2010, 11, 1168; (b) J. C. Jewett and C. R. Bertozzi, Chem. Soc. Rev., 2010, 39, 1272; (c) E. M. Sletten and C. R. Bertozzi, Acc. Chem. Res., 2011, 44, 666; (d) S. Arumugam, S. V. Orski, N. E. Mbua, C. McNitt, G.-J. Boons, J. Locklin and V. V. Popik, Pure Appl. Chem., 2013, 85, 1499; (e) J. Dommerholt, F. P. J. T. Rutjes and F. L. van Delft, Top. Curr. Chem., 2016, 374, 16. 
4 (a) A.-C. Knall and C. Slugovc, Chem. Soc. Rev., 2013, 42, 5131; (b) Z.-J. Zheng, D. Wang, Z. Xu and L.-W. Xu, Beilstein J. Org. Chem., 2015, 11, 2557; (c) S. Yoshida, Bull. Chem. Soc. Jpn., 2018, 91, 1293; (d) S. Yoshida, Org. Biomol. Chem., 2020, 18, 1550.

5 (a) J. Dommerholt, S. Schmidt, R. Temming, L. J. A. Hendriks, F. P. J. T. Rutjes, J. C. M. van Hest, D. J. Lefeber, P. Friedl and F. L. van Delft, Angew. Chem., Int. Ed., 2010, 49, 9422; (b) A. M. Jawalekar, E. Reubsaet, F. P. J. T. Rutjes and F. L. van Delft, Chem. Commun., 2011, 47, 3198; W. Chen, D. Wang, C. Dai, D. Hamelberg and B. Wang, Chem. Commun., 2012, 48, 1736; (c) T. Cruchter, K. Harms and E. Meggers, Chem. - Eur. J., 2013, 19, 16682; (d) D. Wang, W. Chen, Y. Zheng, C. Dai, K. Wang, B. Ke and B. Wang, Org. Biomol. Chem., 2014, 12, 3950; (e) S. Wallace and J. W. Chin, Chem. Sci., 2014, 5, 1742; $(f)$ L. Plougastel, O. Koniev, S. Specklin, E. Decuypere, C. Créminon, D.-A. Buisson, A. Wagner, S. Kolodych and F. Taran, Chem. Commun., 2014, 50, 9376; (g) D. Wang, E. Viennois, K. Ji, K. Damera, A. Draganov, Y. Zheng, C. Dai, D. Merlin and B. Wang, Chem. Commun., 2014, 50, 15890; (h) J. Dommerholt, O. van Rooijen, A. Borrmann, C. F. Guerra, F. M. Bickelhaupt and F. L. van Delft, Nat. Commun., 2014, 5, 5378; (i) T. H. Poole, J. A. Reisz, W. Zhao, L. B. Poole, C. M. Furdui and S. B. King, J. Am. Chem. Soc., 2014, 136, 6167; $(j)$ A. J. Pérez and H. B. Bode, ChemBioChem, 2015, 16, 1588; $(k)$ K. A. Horner, N. M. Valette and M. E. Webb, Chem. - Eur. J., 2015, 21, 14376; (l) J. Hoogenboom, H. Zuilhof and T. Wennekes, Org. Lett., 2015, 17, 5550; (m) A. Borrmann, O. Fatunsin, J. Dommerholt, A. M. Jonker, D. W. P. M. Löwik, J. C. M. van Hest and F. L. van Delft, Bioconjugate Chem., 2015, 26, 257; (n) E. Galardon and D. Padovani, Bioconjugate Chem., 2015, 26, 1013; (o) E. M. Schneider, M. Zeltner, V. Zlateski, R. N. Grass and W. J. Stark, Chem. Commun., 2016, 52, 938; (p) Y. Sun, X. Ma, K. Cheng, B. Wu, J. Duan, H. Chen, L. Bu, R. Zhang, X. Hu, Z. Deng, L. Xing, X. Hong and Z. Cheng, Angew. Chem., Int. Ed., 2015, 54, 5981; $(q)$ H. Liu, D. Audisio, L. Plougastel, E. Decuypere, D.-A. Buisson, O. Koniev, S. Kolodych, A. Wagner, M. Elhabiri, A. Krzyczmonik, S. Forsback, O. Solin, V. Gouverneur and F. Taran, Angew. Chem., Int. Ed., 2016, 55, 12073; (r) R. Sen, Di. Gahtory, R. R. Carvalho, B. Albada, F. L. van Delft and H. Zuilhof, Angew. Chem., Int. Ed., 2017, 56, 4130; (s) S. Bernard, D. Audisio, M. Riomet, S. Bregant, A. Sallustrau, L. Plougastel, E. Decuypere, S. Gabillet, R. A. Kumar, J. Elyian, M. N. Trinh, O. Koniev, A. Wagner, S. Kolodych and F. Taran, Angew. Chem., Int. Ed., 2017, 56, 15612; $(t)$ S. Ursuegui, M. Recher, W. Krężel and A. Wagner, Nat. Commun., 2017, 8, 15242; (u) X. Li, Z. Liu and S. Dong, RSC Adv., 2017, 7, 44470; (v) W. Wang, X. Ji, Z. Du and B. Wang, Chem. Commun., 2017, 53, 1370; (w) P. Werther, J. S. Möhler and R. Wombacher, Chem. Eur. J., 2017, 23, 18216; (x) M. Bjerknes, H. Cheng, C. D. McNitt and V. V. Popik, Bioconjugate Chem., 2017, 28, 1560; (y) L. C.-C. Lee, H. M.-H. Cheung, H.-W. Liu and K. K.-W. Lo, Chem. - Eur. J., 2018, 24, 14064; $(z)$ A. Herrmann, L. Kaufmann, P. Dey, R. Haag and U. Schedler, ACS Appl. Mater. Interfaces, 2018, 10, 11382; (aa) C. Favre and F. Friscourt, Org. Lett., 2018, 20, 4213; $(a b)$ B. J. Levandowski, R. F. Gamache, J. M. Murphy and K. N. Houk, J. Am. Chem. Soc., 2018, 140, 6426; (ac) B. Spangler, S. Yang, C. M. B. Rath, F. Reck and B. Y. Feng, ACS Chem. Biol., 2019, 14, 725; (ad) P. N. Gunawardene, W. Luo, A. M. Polgar, J. F. Corrigan and M. S. Workentin, Org. Lett., 2019, 21, 5547; (ae) B. J. Levandowski, N. S. Abularrage, K. N. Houk and R. T. Raines, Org. Lett., 2019, 21, 8492; (af) M. Baalmann, M. J. Ziegler, P. Werther, J. Wilhelm and R. Wombacher, Bioconjugate Chem., 2019, 30, 1405; (ag) B. J. Levandowski, D. Svatunek, B. Sohr, H. Mikula and K. N. Houk, J. Am. Chem. Soc., 2019, 141, 2224; (ah) P. N. Gunawardene, J. F. Corrigan and M. S. Workentin, J. Am. Chem. Soc., 2019, 141, 11781; (ai) Z.-C. Wu and D. L. Boger, J. Am. Chem. Soc., 2019, 141, 16388; (aj) U. Reisacher, D. Ploschik, F. Rönicke,
G. B. Cserép, P. Kele and H.-A. Wagenknecht, Chem. Sci., 2019, 10, 4032; (ak) L. Plougastel, M. R. Pattanayak, M. Riomet, S. Bregant, A. Sallustrau, M. Nothisen, A. Wagner, D. Audisio and F. Taran, Chem. Commun., 2019, 55, 4582; (al) X. Zhang, X. Wu, S. Jiang, J. Gao, Z. Yao, J. Deng, L. Zhang and Z. Yu, Chem. Commun., 2019, 55, 7187; (am) V. N. Kozhevnikov, M. E. Deary, T. Mantso, M. I. Panayiotidis and M. T. Sims, Chem. Commun., 2019, 55, 14283; (an) H. Noda, Y. Asada, M. Shibasaki and N. Kumagai, Org. Biomol. Chem., 2019, 17, 1813; (ao) R. A. Kumar, M. R. Pattanayak, E. Yen-Pon, J. Eliyan, K. Porte, S. Bernard, M. Riomet, P. Thuéry, D. Audisio and F. Taran, Angew. Chem., Int. Ed., 2019, 58, 14544; (ap) M. Riomet, K. Porte, L. Madegard, P. Thuéry, D. Audisio and F. Taran, Org. Lett., 2020, 22, 2403; (aq) E. Ros, M. Bellido, X. Verdaguer, L. R. de Pouplana and A. Riera, Bioconjugate Chem., 2020, 31, 933; (ar) C. D. Mboyi, D. Vivier, A. Daher, P. Fleurat-Lessard, H. Cattey, C. H. Devillers, C. Bernhard, F. Denat, J. Roger and J.-C. Hierso, Angew. Chem., Int. Ed., 2020, 59, 1149.

6 (a) S. Yoshida, A. Shiraishi, K. Kanno, T. Matsushita, K. Johmoto, H. Uekusa and T. Hosoya, Sci. Rep., 2011, 1, 82; (b) S. Yoshida, T. Nonaka, T. Morita and T. Hosoya, Org. Biomol. Chem., 2014, 12, 7489; (c) T. Meguro, S. Yoshida and T. Hosoya, Chem. Lett., 2017, 46, 1137; (d) S. Yoshida, K. Kanno, I. Kii, Y. Misawa, M. Hagiwara and T. Hosoya, Chem. Commun., 2018, 54, 3705; (e) T. Meguro, N. Terashima, H. Ito, Y. Koike, I. Kii, S. Yoshida and T. Hosoya, Chem. Commun., 2018, 54, 7904; $(f)$ S. Yoshida, J. Tanaka, Y. Nishiyama, Y. Hazama, T. Matsushita and T. Hosoya, Chem. Commun., 2018, 54, 13499; $(g)$ T. Meguro, S. Yoshida, K. Igawa, K. Tomooka and T. Hosoya, Org. Lett., 2018, 20, 4126; $(h)$ T. Meguro, S. Chen, K. Kanemoto, S. Yoshida and T. Hosoya, Chem. Lett., 2019, 48, 582; (i) S. Yoshida, S. Goto, Y. Nishiyama, Y. Hazama, M. Kondo, T. Matsushita and T. Hosoya, Chem. Lett., 2019, 48, 1038; (j) T. Meguro, Y. Sakata, T. Morita, T. Hosoya and S. Yoshida, Chem. Commun., 2020, 56, 4720.

7 (a) S. Yoshida, Y. Hatakeyama, K. Johmoto, H. Uekusa and T. Hosoya, J. Am. Chem. Soc., 2014, 136, 13590; (b) S. Yoshida, T. Kuribara, H. Ito, T. Meguro, Y. Nishiyama, F. Karaki, Y. Hatakeyama, Y. Koike, I. Kii and T. Hosoya, Chem. Commun., 2019, 55, 3556.

8 For an alternative approach, see; R. R. Ramsubhag and G. B. Dudley, Org. Biomol. Chem., 2016, 14, 5028.

9 (a) G. Wittig and H.-L. Dorsch, Liebigs Ann. Chem., 1968, 711, 46; (b) G. Wittig and S. Fischer, Chem. Ber., 1972, 105, 3542; (c) G. Gröger, U. Behrens and F. Olbrich, Organometallics, 2000, 19, 3354; (d) M. Shelbourne, X. Chen, T. Brown and A. H. El-Sagheer, Chem. Commun., 2011, 47, 6257; (e) A. Das, C. Dash, M. Yousufuddin, M. A. Celik, G. Frenking and H. V. R. Dias, Angew. Chem., Int. Ed., 2012, 51, 3940; $(f)$ A. Das, C. Dash, M. A. Celik, M. Yousufuddin, G. Frenking and H. V. R. Dias, Organometallics, 2013, 32, 3135; (g) P. Gobbo, T. Romagnoli, S. M. Barbon, J. T. Price, J. Keir, J. B. Gilroy and M. S. Workentin, Chem. Commun., 2015, 51, 6647.

10 M. A. Bennett and H. P. Schwemlein, Angew. Chem., Int. Ed. Engl, 1989, 28, 1296.

11 (a) X. Ning, J. Guo, M. A. Wolfert and G.-J. Boons, Angew. Chem., Int. Ed., 2008, 47, 2253; (b) X. Ning, R. P. Temming, J. Dommerholt, J. Guo, D. B. Ania, M. F. Debets, M. A. Wolfert, G.-J. Boons and F. L. van Delft, Angew. Chem., Int. Ed., 2010, 49, 3065.

12 (a) R. Ni, N. Mitsuda, T. Kashiwagi, K. Igawa and K. Tomooka, Angew. Chem., Int. Ed., 2015, 54, 1190; (b) Y. Kawasaki, Y. Yamanaka, Y. Seto, K. Igawa and K. Tomooka, Chem. Lett., 2019, 49, 495.

13 Complexes of 1a with transition metals formed as precipitates.

14 Although further detailed studies are required, the selectivity would be concerned with the following two factors; (1) the coordination strength of silver or gold with cycloalkynes is weaker than that of copper and (2) electron-rich and highly strained natures of BCNs strengthen the coordination. 